\title{
Entheogens in Buddhism
}

AKADÉMIAI KIADÓ

Journal of Psychedelic Studies

5 (2021) 1, 1-4

DOl:

$10.1556 / 2054.2020 .00161$

(c) 2020 The Author(s)

\section{BOOK REVIEW}

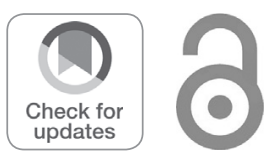

*Corresponding author. E-mail: michaeljwinkelman@gmail. com

\author{
Michael James Winkelman*
}

School of Human Evolution and Social Change, Arizona State University, Tempe, AZ, USA

Crowley, M. (2019). Secret drugs of Buddhism: Psychedelic sacraments and the origins of the Vajrayana. Santa Fe: Synergetic Press. ISBN 9780907791744 (paperback) | ISBN 9780907791751 (ebook) 347 pages with index USD $\$ 19.95$

Received: November 30, 2020 • Accepted: December 13, 2020

Published online: January 19, 2021

Crowley uses his personal engagement with Buddhism and a review and analysis of ancient texts as a basis to address evidence for entheogenic substances in Tibetan Buddhism. Crowley provides a wide-ranging analysis of an idea that has gained increasing popularity-and controversy-that ancient Buddhist practices involved the use of entheogens. Crowley provides analyses of myth and ritual practices that reveal information regarding the identities of entheogenic sacraments of Buddhism and Hinduism.

Crowley places his considerations of entheogen use in the context of the development of the Aryan peoples (Indo-European speakers) and the Indus Valley Civilization (IVC). In contrast to a longstanding view that the entheogenic soma traditions of the Vedas originated in the Indo-Aryan civilization, Crowley contends the Indo-Aryans obtained it from IVC. Depictions of ceramic strainers associated with soma ritual resemble much earlier artifacts of the Harappan civilization, indicating that the prototype Iranian haoma and Indic soma traditions derived from cultural transfer from the IVC sacramental practices. This interpretation is consistent with the lack of central psychoactive sacramental rituals among other ancient Indo-European cultures, the exceptions being the related soma of India and haoma in Iran. Further evidence of IVC origins of Vedic/Brahman deities comes from the Aryan deity Rudra, also identified with Agni ("fire") and Soma. Rudra appears to have been derived from a Dravidian deity that entered the Āryan belief system after they arrived in the Indus Valley since the characteristic features (an archer with horns and a tail) are represented on IVC seals.

This background and arguments are, however, largely incidental to Crowley's main arguments. Crowley's analyses focus on a central myths of a more recent phase (since 500 $\mathrm{BCE}$ ), the period that gave rise to new gods and heroes expressed in the epics Mahābhārata and the Rāmāyana and myths known as purānas ("ancient tales") that conveyed the beliefs of the non-Āryan Indian populations and supported the emergence of Vajrayāna Buddhism. The meanings behind these Vajrayāna deities nonetheless came from Hindu myth and ritual, and it is the tracing of these similarities between the deities of Hindu and Vajrayāna in their characteristics that provides the basis of Crowley's arguments that Buddhist amrita is the Vedic soma.

Crowley's analysis focuses on the Vedic myth called The Churning of the Ocean, a later account of the origins of soma sacrament. Here we learn of how the Vedic gods stole soma from the asuras, a group outside of the castes that represented the shamanic practitioners of the IVC.

Crowley analyzes and compares the Vedic account with the Tibetan Buddhist Vajrayāna text Immaculate Crystal Garland which recounts the principal events of the Churning of the Ocean myth, showing its origins in the earlier Sanskrit version. The parallels between Tibetan Buddhist accounts of the origin of amrita as described in The Immaculate Crystal Garland and the origins of soma as related in The Churning of the Ocean reveals the origins of the Buddhist amrita in the Vedic soma. While soma and amrita are used interchangeably in Hinduism, the entheogen is only referred to as amrita in Vajrayāna Buddhism.

Crowley links the features of various Vajrayāna deities to the red cap or other features of the fly agaric mushroom or the purple-necked Psilocybe cubensis. Another significant entheogenic feature involves one of the fourteen "treasures" Kamadhenu (meaning, "desire- 
milk"), a wish-granting cow adorned with wings and peacock feathers which gives amrita instead of milk.

A repeated feature of Crowley's analysis of entheogenic evidence in scriptural accounts involves sories of drinking urine or replacing somalamrita with urine, activities not explained within scriptural contexts, but which nonetheless provide clues to the identity of soma and amrita. The substitution of the hunter god's urine for amrita has parallels in the Siberian Amanita muscaria practices. This strange habit is a key sign of A. muscaria consumption attested to in Siberian groups who take advantage of enhanced psychoactive effects by the liver's conversion of the mushroom's ibotenic acid to the less toxic but highly psychoactive muscimol excreted in the urine of humans or reindeer.

Crowley argues for a different entheogenic identity to Śiva revealed by his Sanskrit name, nillakāntha, meaning "blue throat", which he proposes alludes to typical features of psilocin containing mushrooms, which bruise blue. This fungal identification is further supported by the one-legged (stem-like) feature ascribed to Siva; his epithet of "Lord of Herbs" and association with several psychoactive drugs; mushroom-shaped Śiva temples called "mushroom-like" (Skt. chattraka); references to Siva as Lord of Amrita; and the body of literature and oral teachings regarding Siva known as "the science of soma."

Crowley uses his comparative method to identify further entheogenic references in the frequent scriptural accounts regarding peacocks. The necks of the vessels used for amrita normally have peacock feathers. The Sanskrit literature frequently refers to the peacock as a "blue throat" (Skt. Nilakantha), reflecting both its physical characteristics, a homology with Śiva, and the features of the psychedelic mushroom P. cubensis. The peacock's direct relationship with this deity is reflected in the accounts of the Churning of the Ocean where the peacock drinks a poison and consequently saves the world from death, but consequently turning its throat blue, giving the peacock the name "blue throat."

The Buddhist deity "Blue-throat" (Skt. nīlakāntha lokeśvara) has the defining features of Vishnu-discus, club, conch and lotus-as well as Śiva's name. Crowley proposes this conflation of the attributes of the two gods represents their functional equivalence derived from the interchangeability of P. cubensis and A. muscaria mushrooms for soma/ amrita.

Crowley proposes references to amrita in Japanese Buddhism texts, myths and mantras are provide by depictions of various deities with mushroom forms that have unusual features which resemble various entheogenic species of the Psilocybe genus characteristic of the region (Psilocybe liniformans, Psilocybe argentipes). A specific focus involves parasols or umbrellas, which have two principal functions within Buddhist art. The most common involves its placement over the head of a Buddha, a use similar to the use by Indian king to symbolize royal status.
Another use involves it being held by a deity with the umbrellas' characteristics revealing defining attributes of the deity. Various references to the blue neck and staff of the parasol reflect the dark ring hanging on the mushroom's stem that is characteristic of P. cubensis; and the tendency of the flesh to bruise blue that is characteristic of psilocybin-containing species.

Crowley (2015) focuses on the Japanese Buddhist deities named Ușnissas, referring to a "crown-bump" (umbo) or cranial protrusion that characterizes depictions of many Buddhas. Crowley examines the characteristics and representations of the "Crown-bump White parasol Lady" deity to show these reflect descriptions of Psilocybe species. This Ușnìsasitātapatrā is connected not just with parasols, an iconic symbol of mushrooms, but also with a group of deities featuring a peculiar bump on the Buddha's head. This feature is shared by a class of Vajrayāna deities (Chinese, Tibetan and Japanese) generically called Ușn̄̄sas (referring to the crown of the head). The numerous and widespread Ușnissa deities indicate that they represent important features of Buddhist practice, but the many striking names revealing the features of the parasols or umbrellas (i.e., "Supremely Excellent White Parasol" and "Supremely Excellent Umbrella") emphasize characteristics that do not have a traditional explanation.

Crowley argues that the parasol and umbrella names are linked to psychedelic mushrooms as descriptions of the qualities and characteristics of various entheogenic mushroom species. Crowley analyzes the usnissa, a crown bump found on the heads of many depictions of Buddha in the context of mushroom caps where many species show a small bump in the center of the cap. This bump which mycologists refer to as an "umbo," is manifested in both sharply pointed and gently rounded forms. He notes additional correspondences of $P$. argentipes with bodhisattva Sitātapatrabuddhosnīsa, including descriptions of the cap margin edges and veil fragments.

Crowley points to corroboration of the entheogenic referent intended by these parasol and crown bump deities found in Vajrayāna literature coded allusions to amrita. The distinctions among the usnissas include subtle color variants that are not part of traditional mandala and tantric art distinctions but subtle shade differences, such as pale yellow, yellow, golden, saffron and white and offwhite, which are the kind of color variations found in these mushrooms. Other usnīsa have names which are traditional synonyms for amrita (and soma in the Vedic texts) such as jaya ("victory") and vijaya ("conquest"), referring to the battle that the gods fought to defeat the demons and gain access to soma. Further analyses of the meanings of the names of the various Usnissa's provide confirmation of his interpretation of entheogenic mushrooms in features that reflect the physical features of the mushrooms such as sprouting, their specific colors, their wheel-like shapes, their growing seasons (rain), and their effects (quick acting, vomiting). 
Crowley further establishes the entheogenic activities by linking the phenomenal descriptions of the Vajrayana Buddhist monks' experiences of amrita to the known effects of entheogens, showing how the sequence of experiences correspond to the stages of entheogenic experiences. Passages of Dzogchen texts describe experiences resembling typical features of psychedelic experiences (warmth, bliss, dissolution of self, inner transformation). Buddhist traditions are characterized by features that indicate the influences of psilocybin: rapid, in one life-time enlightenment (peak psychedelic experiences); extensive visualization exercises (facilitated by psilocybin effects on the visual system); and non-dualism (ego-loss caused by psilocybin).

Crowley notes an obvious objection to his entheogenic hypothesis of amrita in the formal vow Buddhists monks take to avoid use of intoxicants. He rightly questions whether psychedelics should be considered intoxicants substances that cloud the mind-as opposed to agents that clear the mind, perceptions and understandings, allowing "a clearer, less deluded, mode of appreciating one's reality".

Crowley concludes his arguments by pointing out that many Buddhist (and Vedic) deities clearly represent the properties of psychedelic plants and fungi. Sometimes they are symbolic, but in many cases they are literal, such as the physical conditions of excessive sweating, a characteristic effect of muscimol, one of the active principles A. muscaria, which acts on acetylcholine receptors.

No one can reasonably doubt that psychoactive substances - even so-called drugs - were used in Indian religions, especially Cannabis and Datura. These leave no doubt of the acceptability of mind-altering substances in Indic spiritual traditions. Crowley summarizes his arguments in pointing out the presence of various psilocybincontaining species, and suggests these were originally P. cubensis and eventually other species (Ps. liniformans, Ps. argentipes and Panaeolus cambodginiensis) as Buddhism was established in countries without the tropical environments that support $P$. cubensis.

There is a certainty to Crowley's findings, even though there are weakness in his scholarship, for instance his frequent assertion of the agreement with him of "most scholars" without citing any. Or when he asserts that "Every Psilocybe has an umbo" (raised bump on center of cap), but without any supporting reference. Crowley lacks citations to authoritative sources for his many broad and specific claims, refers to online videos as citations to important claims, and references encyclopedias instead of primary sources in various fields. Furthermore, while Crowley has many footnotes, some are missing references. The lack of a critical editor has left some passages that seem absurd, for instance 'It is now clear why the tantric feasts of the ancient siddhas allowed "peacock meat" as an acceptable substitute for "beef." They both tasted exactly like psychedelic mushrooms' (p. 146). Whatever secret language Crowley might be using is beyond this reader.
Perhaps more concerning are the botanical identities of the entheogens proposed by Crowley. Crowely proposes entheogenic identities in species alleged to be native to India including $P$. cubensis, Copelandia cyanescens, Psilocybe semilanceata, Panaeolus campanulatus. (syn. Pan. papilionaceus), and as well as P. cambodginiensis, Ps. kashmiriensis Ps. liniformans and Ps. argentipes but sources for these claims are weak or uncited. Guzman, Allen, and Gartz (1998) only report the first four species above for India (but not the last four species); however, they also report nearly two dozen additional psilocybian species for India. One of the species proposed by Crowley as a soma/ amrita substance ( $P$. campanulatus, syn. Pan. papilionaceus) does not appear to be psychoactive (Stijve, 1985; Gurevich, 1993; Andersson, Kristinsson, \& Gry, 2009; also see; Allen, 2013) in spite of frequently undocumented claims alleging its psychoactivity.

But these various shortcomings do not refute Crowley's basic argument-that psychedelics were a core part of early Buddhist initiation and experiences. Crowley's book is informative, showing his familiarity with a number of areas of Buddhist and Hindu scholarship, particularly Vajrayana Buddhism. His assertions are frequently referenced, even if his interpretations go beyond the claims his sources made.

The many double-blind studies that show the empirical ability of psychedelics to induce valid mystical experiences is modern evidence that strongly supports Crowley's core argument-entheogens have had-and continue to have-a significant role in supporting spiritual development (see Roberts, 2020).

This obvious fact to the field of entheogenic studies is met with curious silences from religious scholars and communities. Here is the evidence of your sacraments, obviously sculptured into the thresholds of your temples (Maillart-Garg and Winkelman, 2019). These are entheogenic mushrooms with numerous spiritual and health benefits discovered by modern science (see Winkelman and Sessa, 2019).

This book presents a challenge to the Buddhists of the world. Why have you not embraced your heritage? Is it lost or thought irrelevant? Or is it still used by the elite or monks in secrecy?

Michael James Winkelman*

\section{REFERENCES}

Allen, J. (2013). [Jan-Dec, 2012]. A chemical referral and reference guide to the known species of psilocine and/or psilocybinecontaining mushrooms and their published analysis and bluing reactions: An updated and revised list. Ethnomycological Journals: Sacred Mushroom Studies, IX(1-2), 127-166. 
Andersson, C., Kristinsson, J., \& Gry, J. (2009). Occurrence and use of hallucinogenic mushrooms containing psilocybin alkaloids. Copenhagen: Nordic Council of Ministers.

Gurevich, L. (1993). Indole derivatives in certain Panaeolus species from East Europe and Siberia. Mycological Research, 97(2), 251-254. https://doi.org/10.1016/S0953-7562(09)80249-9.

Guzman, G., Allen, J., \& Gartz, J. (1998). A world wide geographical distribution of the neurotropic fungi, an analysis and discussion. Annali del Museo civico di Rovereto, 14, 189-280.

Maillart-Garg M., \& Winkelman M. (2019). The "Kamasutra" temples of India: A case for the encoding of psychedelically induced spirituality, Journal of Psychedelic Studies Special Issue: Psychedelics in History and World Religions, 3(2019), 81-103. http://doi.org/10.1556/2054.2019.012.

Roberts T. (Ed.). (2020). Psychedelics and spirituality: The sacred use of LSD, psilocybin, and MDMA for human transformation. Rochester, VT: Park Street Press.

Stijve, T. (1985). Een chemische verkenning van het geslacht Panaeolus. Coolia, 28(4), 81-89.

Winkelman, M., \& Sessa, B. (Eds.) (2019). Advances in psychedelic medicine state of the art therapeutic applications. Santa Barbara: ABC-CLIO. 